\title{
Serum antibody response in COVID-19-recovered patients who retested positive
}

\author{
Nicole Atchessi ${ }^{1}$, Megan Striha ${ }^{1}$, Rojiemiahd Edjoc ${ }^{1 *}$, Christine Abalos ${ }^{1}$, Amanda Lien', \\ Lisa Waddell', Imran Gabrani-Juma ${ }^{1}$, Emily Thompson ${ }^{1}$, Thomas Dawson ${ }^{1}$
}

\begin{abstract}
Background: Research studies comparing antibody response from coronavirus disease 2019 (COVID-19) cases that retested positive (RP) using reverse transcription polymerase chain reaction (RT-PCR) and those who did not retest positive (NRP) were used to investigate a possible relationship between antibody response and retesting status.
\end{abstract}

Methods: Seven data bases were searched. Research criteria included cohort and case-control studies, carried out worldwide and published before September 9, 2020, that compared the serum antibody levels of hospitalized COVID-19 cases that RP after discharge to those that did NRP.

Results: There is some evidence that immunoglobulin $\mathrm{G}(\operatorname{lgG})$ and immunoglobulin $\mathrm{M}$ ( $\operatorname{lgM})$ antibody levels in RP cases were lower compared with NRP cases. The hypothesis of incomplete clearance aligns with these findings. The possibility of false negative reverse transcription polymerase chain reaction (RT-PCR) test results during viral clearance is also plausible, as concentration of the viral ribonucleic acid (RNA) in nasopharyngeal and fecal swabs fluctuate below the limits of RT-PCR detection during virus clearance. The probability of reinfection was less likely to be the cause of retesting positive because of the low risk of exposure where cases observed a 14 day-quarantine after discharge.

Conclusion: More studies are needed to better explain the immune response of recovered COVID-19 cases retesting positive after discharge.
This work is licensed under a Creative Commons Attribution 4.0 International License.

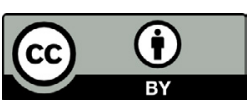

Affiliations

${ }^{1}$ Health Security and Operations Branch, Public Health Agency of Canada, Ottawa, ON

2 Public Health Risk Sciences Division, National Microbiology Laboratory, Public Health Agency of Canada, Winnipeg, MB

*Correspondence:

rojiemiahd.edjoc@canada.ca

Suggested citation: Atchessi N, Striha M, Edjoc R, Abalos C, Lien A, Waddell L, Gabrani-Juma I, Thompson E, Dawson T. Serum antibody response in COVID-19-recovered patients who retested positive. Can Commun Dis Rep 2021;47(4):195-201. https://doi.org/10.14745/ccdr.v47i04a03

Keywords: COVID-19, SARS-CoV-2, RT-PCR, false-negative, reinfection, retesting

\section{Introduction}

Coronavirus disease 2019 (COVID-19) is a novel disease that results from infection by severe acute respiratory syndrome coronavirus 2 (SARS-CoV-2) (1). On December 31, 2019, a case of pneumonia of unknown cause was identified in Wuhan, China and reported to the World Health Organization (WHO) Country Office. The cause of the disease was later confirmed to be a novel coronavirus (2). The SARS-CoV-2 outbreak was declared a pandemic by WHO on March 11, 2020 (3). As of October $14,2020,75 \%$ of the $38,508,475$ internationally confirmed cases of COVID-19 have recovered (4). However, there is evidence that some recovered COVID-19 cases discharged from hospital with negative COVID-19 tests later retested positive (RP) (5).

\section{Current situation}

The situation of recovered and discharged COVID-19 cases retesting positive raise concerns of potential reinfection or incomplete clearance of the virus, as well as questions related to a patient's infectiousness. Multiple hypotheses have been put forward to explain the reasons why some cases RP after discharge with negative reverse transcription polymerase chain reaction (RT-PCR) test results. The purpose of this review is to explore the current evidence regarding differences in antibody response between discharged COVID-19 cases that RP and those that did not retest positive (NRP). 


\section{Methods}

Our research criteria included cohort and case-control studies carried out across the world and published before September 9, 2020 , that compared the serum antibody level of hospitalized COVID-19 cases that RP after discharge to those that did not. Seven databases were searched. Search terms used included the following: reactivation; reinfection; reoccurrence; recurrent; in conjunction with hospitalization; discharge; antibody; and immunity. Articles $(n=224)$ were screened for relevance and included studies were evaluated with the Newcastle-Ottawa Scale Risk of Bias Tool according to criteria related to the selection of the cases (score $=4$ ), the comparability of RP cases to NRP cases (score $=2$ ) and the assessment of the exposure or the outcome (score=3). A total of nine studies were found to be relevant (see Appendix A). A follow-up of at least four weeks was considered as adequate in cohort studies. The assessment was done by two reviewers (see Appendix B).

\section{Results}

We identified three prospective cohort studies (6-8), three retrospective cohort studies (9-11), two cohort studies (unclear if prospective or retrospective) $(12,13)$ and one case-control study (14).

The sample size of the nine studies varied from 74 to 619. The prevalence of COVID-19 cases that experienced a reoccurrence of a positive PCR test after meeting discharge criteria of two consecutive negative RT-PCR tests more than 24 hours apart, varied from $7 \%$ to $21 \%$ in seven out of eight cohort studies $(6-8,10-14)$, with the ninth study finding $58 \%$ RT (9). The average prevalence for the eight cohort studies was $16.6 \%$ ( $n=382 / 2,305$ cases). Of the six studies that captured information on the time between testing negative at discharge and RP the first time post discharge, the median time across studies varied from 4.6 days to 12 days $(6,8,10,11,13,14)$. The RP cases were significantly younger in four studies $(6,8,13,14)$; however, no age difference was found in the five other studies (7,9-12). No association with sex was reported in any study.

Six studies reported on the positivity rate of immunoglobulin $\mathrm{G}(\mathrm{lgG})$ and immunoglobulin $\mathrm{M}$ (IgM) antibodies (7,8,10-13), while four specified their serum levels $(8,9,12,14)$. There were no differences in $\operatorname{lgG}$ and $\operatorname{lgM}$ antibody positivity rates between RP and NRP cases $(6-8,10-13)$; however, the level of $\lg G(9,14)$ and/or IgM $(8,14)$ antibodies in the serum was lower in RP cases compared with NRP cases in three studies. No difference was observed in either $\lg M(9,12)$ or $\lg G$ level $(8,12)$ in the other studies.

\section{Discussion}

There are several possible explanations for what a RP result following discharge such as low viral load in samples, false negative results in RT-PCR tests and re-infection. The most likely explanation is a false negative RT-PCR result due to 1) viral ribonucleic acid (RNA) concentration decreasing to levels below the limit of detection of the test during viral clearance and 2) the expected proportion of false negative results in RT-PCR tests.

According to Liu et al. (12), given that the presence of IgM antibodies was similar in both cases who RP and NRP, the RP RT-PCR tests in their review of 619 cases were unlikely to be due to reinfection with SARS-CoV-2 virus. The studies included in this review mainly monitored cases during the post-discharge 14-day quarantine period, which would also rule out re-infection as a likely explanation for RP results shortly after discharge.

According to Yang et al., false negative RT-PCR results could also result from low virus concentrations in samples from nasopharyngeal or fecal swabs despite viruses still being present in the lower respiratory tract, leading to intermittent or fluctuating excretion of viral RNA in the upper respiratory tract (8).

Wölfel et al. reported that the RT-PCR for SARS-CoV-2 is an imperfect test, with a sensitivity of $89 \%$ and, thus, an expected proportion of $11 \%$ false negative results (15). Zou (11) found that performing three consecutive tests prior to discharge significantly reduced the chance of $\mathrm{RP}$, which is consistent with the false-negative results hypothesis.

The findings that relate lower level of antibodies to RP suggest that cases that RP were more likely to have a weaker immune response, which aligns with the hypothesis of a viral clearance. According to Yuan (7), the lowest prevalence of subsequent positive tests experienced by cases with severe symptoms compared with those experiencing mild symptoms can be explained by a stronger immune response activated in severely ill cases that clears the virus more effectively.

One of the main concerns that arise from cases RP is the infectiousness of cases after discharge. While some authors argued that the risk of infectiousness during this period is low $(8,16)$, others claimed the opposite and even mention the possibility of chronic infection with SARS-CoV-2 (12). This latter assumption casts doubt on the protective role of lgG antibodies and of using serology testing to establish immunity.

The findings of this review seemed to be supportive of an association between antibody response and RP after discharge. There is some evidence that $\lg G$ and $\lg M$ antibodies levels in RP cases are lower compared with NRP cases. The hypothesis of incomplete clearance also aligns with these findings. 


\section{Limitations}

The current review has several limitations. Five out of nine studies had a sample size of less than 200 and all studies were restricted to China, which limits the representativeness of the review. We were unable to find research outside of China that had serology results, a comparison group and had follow-up RT-PCR testing to establish RP status. Among the included studies, the duration of follow-up after discharge and RT-PCR testing intervals varied, which could impact the results related to the timing and prevalence of RP results summarized in this study. In addition, eight out of nine studies were based on discharged cases but no information about their representativeness of hospitalized cases was provided. Further, the lack of comparison of cases with incomplete medical records or lost to follow-up to those that remained in the studies limits the assessment of potential bias estimates. This study included studies published up to September 2020 and should be interpreted accordingly, given the rapid evolution of the evidence. It could be valuable for future studies to focus on testing practices that could reduce the probability of false negative tests to ensure that hospitalized COVID-19 cases meet the required criteria before their discharge.

None of the studies examined the potential association in a multivariable analysis with antibody response to determine the adjusted associations after controlling for potential confounders.

\section{Conclusion}

The situation of COVID-19 cases subsequently RP for COVID-19 after having two negative RT-PCR test results is not uncommon. Evidence suggests a relationship between RP cases and age $(6,8,13,14)$ and possibly between RP and disease severity. However, none of the studies examined the potential association in a multivariable analysis with antibody response to determine the adjusted associations after controlling for potential confounders. Additional evidence synthesis work with proper observational studies on the characteristics of COVID-19 cases that RP is needed to better understand who is likely to RP. Similarly, additional research and synthesis work on immune response and immunity is needed to improve our understanding of COVID-19 infection.

The evidence summarized in this report may have important implications for public health and management of recovered COVID-19 cases. There was a limited number of studies that met the inclusion criteria; however, the evidence suggests the immune response in convalescent COVID-19 cases may be associated with the incomplete viral clearance. These preliminary results can be used to inform further research or decision making on this topic.

\section{Authors' statement}

NA - Methodology, investigation, writing-original draft, review and editing

MS - Methodology, investigation, writing-original draft, review and editing

RE - Conceptualization, methodology, investigation, writing-original draft, review and editing, supervision CA - Writing-original draft, review and editing

$\mathrm{AL}$ - Writing-original draft, review and editing

LW - Writing-review and editing

IGJ - Writing-review and editing

ET - Writing-review and editing

TD - Writing-review and editing

\section{Competing interests}

None to declare.

\section{Acknowledgements}

We would like to thank our colleagues at the Emerging Sciences Group at the Public Health Agency of Canada for their support on this work.

\section{Funding}

None to declare.

\section{References}

1. Wu Z, McGoogan JM. Characteristics of and Important Lessons From the Coronavirus Disease 2019 (COVID-19) Outbreak in China: Summary of a Report of 72314 Cases From the Chinese Center for Disease Control and Prevention. JAMA 2020;323(13):1239-42. DOI PubMed

2. World Health Organization. WHO Director-General's opening remarks at the Mission briefing on COVID-19 - 9 April 2020. Geneva, Switzerland: WHO; 2020 (accessed 2020-05-08). https://www.who.int/dg/speeches/detail/ who-director-general-s-opening-remarks-at-the-mission-brie fing-on-covid-19---9-april-2020

3. World Health Organization. WHO Director-General's opening remarks at the media briefing on COVID-19 - 11 March 2020. Geneva, Switzerland: WHO; 2020 (accessed 2020-09-04). https://www.who.int/dg/speeches/detail/ who-director-general-s-opening-remarks-at-the-media-briefi ng-on-covid-19---11-march-2020

4. Worldometer. COVID-19 Coronavirus pandemic. Worldometer; 2020 (accessed 2020-10). https://www. worldometers.info/coronavirus/ 
5. Lan L, Xu D, Ye G, Xia C, Wang S, Li Y, Xu H. Positive RT-PCR Test Results in Patients Recovered From COVID-19. JAMA 2020;323(15):1502-3. DOI PubMed

6. Lu J, Peng J, Xiong Q, Liu Z, Lin H, Tan X, Kang M, Yuan R, Zeng $L$, Zhou $P$, Liang $C$, Yi L, du Plessis L, Song T, Ma W, Sun J, Pybus OG, Ke C. Clinical, immunological and virological characterization of COVID-19 patients that test re-positive for SARS-CoV-2 by RT-PCR. EBioMedicine 2020;59:102960. DOI PubMed

7. Yuan B, Liu HQ, Yang ZR, Chen YX, Liu ZY, Zhang K, Wang C, Li WX, An YW, Wang JC, Song S. Recurrence of positive SARS-CoV-2 viral RNA in recovered COVID-19 patients during medical isolation observation. Sci Rep 2020;10(1):11887. DOl PubMed

8. Yang $C$, Jiang $M$, Wang $X$, Tang $X$, Fang $S$, Li $H$, Zuo $L$, Jiang $Y$, Zhong $Y$, Chen $Q$, Zheng $C$, Wang $L$, Wu S, Wu W, Liu H, Yuan J, Liao X, Zhang Z, Shi X, Geng Y, Zhang $H$, Zheng $\mathrm{H}$, Wan $\mathrm{M}$, Lu L, Ren X, Cui Y, Zou X, Feng T, Xia J, Yang R, Liu Y, Mei S, Li B, Yang Z, Hu Q. Viral RNA level, serum antibody responses, and transmission risk in recovered COVID-19 patients with recurrent positive SARS-CoV-2 RNA test results: a population-based observational cohort study. Emerg Microbes Infect 2020;9(1):2368-78. DOl PubMed

9. Hu Q, Cui X, Liu X, Peng B, Jiang J, Wang X, Li Y, Hu W, Zo Z, Duan J, Wang X, Zhu L, Gu G, Guo S. The production and clinical implications of SARS-CoV-2 antibodies. medRxiv. 2020.04.20.20065953. DOI

10. Zhu H, Fu L, Jin $Y$, Shao J, Zhang $S$, Zheng $N$, Fan L, Yu Z, Ying J, Hu Y, Chen T, Chen Y, Chen M, Chen M, Xiong Z, Kang J, Jin J, Cai T, Ye H. Clinical features of COVID-19 convalescent patients with re-positive nucleic acid detection. J Clin Lab Anal 2020;34(7):e23392. DOI PubMed

11. Zou $Y$, Wang B-R, Sun $L$, Xu S, Kong Y-G, Shen L-J, Liang G-T, Chen S-M. The issue of recurrently positive patients who recovered from COVID-19 according to the current discharge criteria: investigation of patients from multiple medical institutions in Wuhan, China. J Infect Dis 2020;222(11);1784-8. DOI
12. Liu T, Wu S, Zeng G, Zhou F, Li Y, Guo F, Wang X. Recurrent positive SARS-CoV-2: immune certificate may not be valid. J Med Virol 2020;92(11):2384-6. DOI PubMed

13. Huang J, Zheng L, Li Z, Hao S, Ye F, Chen J, Yao X, Liao J, Wang S, Zeng M, Qiu L, Cen F, Huang Y, Zhu T, Xu Z, Ye M, Yang Y, Wang G, Li J, Wang L, Qu J, Yuan J, Zheng W, Zhang Z, Li C, Whitin JC, Tian L, Chubb H, Hwa K-Y, Gans HA, Ceresnak SR, Zhang W, Lu Y, Maldonado YA, He Q, Wang Z, Liu Y, McElhinney BD, Sylvester KG, Cohen HL, Liu L, Ling XB. Recurrence of SARS-CoV-2 PCR positivity in COVID-19 patients: a single center experience and potential implications. medRxiv. 2020.05.06.20089573. $\mathrm{DOI}$

14. Chen L, Zhang Z-Y, Zhang $X$, Zhang S-Z, Han Q-Y, Feng Z-P, Fu JG, Xiao X, Chen HM, Liu L-L, Chen X-L, Lan Y-P, Zhong D-J, Hu L, Wang J-H, Yin Z-Y. Clinical Characteristics of Recurrent-positive Coronavirus Disease 2019 after Curative Discharge: a retrospective analysis of 15 cases in Wuhan China. medRxiv. 2020.07.02.20144873. DOI

15. Kim H, Hong $\mathrm{H}$, Yoon SH. Diagnostic Performance of CT and Reverse Transcriptase Polymerase Chain Reaction for Coronavirus Disease 2019: A Meta-Analysis. Radiology 2020;296(3):E145-55. DOl PubMed

16. Wölfel R, Corman VM, Guggemos W, Seilmaier M, Zange $S$, Müller MA, Niemeyer D, Jones TC, Vollmar P, Rothe C, Hoelscher M, Bleicker T, Brünink S, Schneider J, Ehmann R, Zwirglmaier K, Drosten C, Wendtner C. Virological assessment of hospitalized patients with COVID-2019. Nature 2020;581(7809):465-9. DOI PubMed 


\section{Appendices}

\section{Appendix A: Serological characteristics of discharged hospitalized coronavirus disease 2019 cases who retested reverse transcription polymerase chain reaction-positive compared with those that did not test positive}

\begin{tabular}{|c|c|c|}
\hline $\begin{array}{l}\text { Description of study } \\
\text { (reference and type, } \\
\text { location and dates } \\
\text { of study) }\end{array}$ & Report details & Key findings and limitations \\
\hline $\begin{array}{l}\text { Lu et al., } 2020 \text { (6) } \\
\text { Prospective cohort } \\
\text { study } \\
\text { Guangdong, China } \\
\text { Jan 23-Feb 19, } 2020\end{array}$ & $\begin{array}{l}\text { - This study followed } 619 \\
\text { discharged cases and serology } \\
\text { was the main outcome: } \\
288 \text { cases had serological } \\
\text { testing a median of } 35 \\
\text { days post symptom onset } \\
\text { (range=23-47 days). } \\
\text { - Cases were followed for } \\
66 \text { days post discharge, and RP } \\
\text { on day } 10 \text { on average (tested } \\
\text { on day } 7 \text { and } 14 \text { only). }\end{array}$ & $\begin{array}{l}\text { - Neutralizing antibody titers for RP and NRP cases were not significantly different } \\
14 \text { days post hospital discharge. } \\
\text { - This study had the largest cohort that was followed for the longest period of time, } \\
\text { recording a RP incidence rate of } 14 \% \text { ( } n=87 / 619 \text { cases). } \\
\text { - RP cases in this study were significantly younger than NRP cases. Sex distribution } \\
\text { did not differ between groups. } \\
\text { Limitations: } \\
\text { - It was not mentioned if the discharged cases involved in the study were } \\
\text { - Sepresentative of the hospitalized cases. } \\
\text { selection criteria were not mentioned. }\end{array}$ \\
\hline $\begin{array}{l}\text { Yang et al., } 2020 \text { (8) } \\
\text { (Preprint) } \\
\text { Prospective cohort } \\
\text { study } \\
\text { Shenzhen, China } \\
\text { Feb 1-May 5, } 2020\end{array}$ & $\begin{array}{l}\text { - This study followed } 479 \\
\text { discharged cases. Serology } \\
\text { is main outcome, with serum } \\
\text { specimens collected on the } \\
1^{\text {st }} 3^{\text {rd }}, 7^{\text {th }} \text {, and } 14^{\text {th }} \text { days post- } \\
\text { discharge. } \\
\text { - Cases were followed for } 90 \\
\text { days post discharge, and } \\
\text { retested positive on day } 8 \text { on } \\
\text { average. An average of } 46 \text { days } \\
\text { elapsed between disease onset } \\
\text { and the final RP event for each } \\
\text { patient. }\end{array}$ & $\begin{array}{l}\text { - RP and NRP cases did not differ in rates of testing positive for IgG antibodies ( } 99 \% \\
\text { and } 98 \% \text {, respectively). Serum levels of IgG antibodies also did not differ between } \\
\text { groups at any point after disease onset. } \\
\text { - RP and NRP cases did not differ in rates of testing positive for IgM antibodies } \\
\text { ( } 37 \% \text { and } 50 \% \text {, respectively). Serum levels of IgM antibodies differed between } \\
\text { groups at different points post-disease onset: At week 3, RP cases had significantly } \\
\text { higher levels of IgM, while at weeks } 6 \text { through } 8, R P \text { cases had significantly lower } \\
\text { IgM levels. } \\
\text { - The incident rate of RP in this study was } 19 \%(n=93 / 479 \text { cases). In addition, } 45 \\
\text { (9\%) experience multiple RP events: two ( } n=32,7 \%) \text {, three }(n=9,2 \%) \text {, or four ( } n=4 \text {, } \\
\text { - } 1 \% \text { ) RP events. } \\
\text { RP cases in this study were significantly younger than NRP cases ( } 34 \text { years } \\
\text { compared with } 45 \text { years). Sex distribution did not differ between groups. } \\
\text { Limitations: } \\
\text { - It was not mentioned if the discharged cases involved in the study were } \\
\text { representative of the hospitalized cases. } \\
\text { - From the } 504 \text { cases in the cohort, } 25 \text { were excluded because of the lack of } \\
\text { information in their medical records. }\end{array}$ \\
\hline $\begin{array}{l}\text { Yuan et al., } 2020 \text { (7) } \\
\text { Prospective cohort } \\
\text { study } \\
\text { Shenzhen, China } \\
\text { Before Apr 21, } 2020\end{array}$ & $\begin{array}{l}\text { - This prospective cohort study } \\
\text { followed } 182 \text { discharged } \\
\text { cases. Serology is one of the } \\
\text { main outcomes of this study, } \\
\text { with } 147 \text { cases submitting for } \\
\text { serological testing on the } 7^{\text {th }} \\
\text { and } 14^{\text {th }} \text { day after discharge. } \\
\text { Cases were followed for } 14 \\
\text { days. Patients were followed } \\
\text { during the mandatory } 14-\text { day } \\
\text { quarantine following hospital } \\
\text { discharge and retested on day } \\
7 \text { and } 14 \text { of quarantine. }\end{array}$ & $\begin{array}{l}\text { - RP and NRP cases did not differ in rates of testing positive for IgG antibodies } \\
\text { - } 100 \% \text { and } 99.2 \% \text {, respectively). } \\
\text { RP and NRP cases did not differ in rates of testing positive for IgM antibodies } \\
\text { (71.4\% for both). } \\
\text { - The incident rate of RP in this study was } 11 \%(20 / 182 \text { cases). } \\
\text { RP cases were not significantly younger in this study, however, cases under } 18 \\
\text { years of age were overrepresented in the RP group. Sex distribution did not differ } \\
\text { between groups. } \\
\text { Limitations: } \\
\text { - The selection criteria of the population involved in the study was not specified. } \\
\text { - Since the serology test was done on a voluntary basis, only a subset had serology } \\
\text { results ( } 14 \text { RP cases and } 133 \text { NRP cases). No information was provided about the } \\
\text { differences between those that did the serology test and those that did not. }\end{array}$ \\
\hline $\begin{array}{l}\text { Zhu et al., } 2020 \text { (10) } \\
\text { Retrospective cohort } \\
\text { study } \\
\text { Zhejiang, China } \\
\text { Before Apr 2, } 2020\end{array}$ & $\begin{array}{l}\text { - This retrospective cohort study } \\
\text { followed } 98 \text { discharged cases. } \\
\text { Serology was part of a wide } \\
\text { range of factors examined, with } \\
\text { testing measuring temporal } \\
\text { changes in antibody levels. } \\
\text { The exact timing of tests is not } \\
\text { stated. } \\
\text { - Cases were followed for at least } \\
17 \text { days following discharge, } \\
\text { with the average time to RP } \\
\text { being } 7 \text { days. }\end{array}$ & $\begin{array}{l}\text { - In this study, } 35.5 \% \text { of RP cases tested positive for both IgG and IgM antibodies, } \\
\text { compared to } 8.6 \% \text { of NRP cases. } 58.8 \% \text { of RP cases tested positive for IgG and } \\
\text { negative for lgM antibodies, compared to } 44.4 \% \text { of NRP cases. Two RP and one } \\
\text { NRP cases tested negative for both IgG and IgM antibodies. The groups were not } \\
\text { significantly different. } \\
\text { - The incident rate of RP was } 17 \% \text { ( } 17 / 98 \text { cases). } \\
\text { - Neither age nor sex was found to differ between RP and NRP cases. } \\
\text { Limitations: } \\
\text { - Only convalescent patients were followed. It was not specified if they were } \\
\text { representative of hospitalized patients. }\end{array}$ \\
\hline
\end{tabular}


Appendix A: Serological characteristics of discharged hospitalized coronavirus disease 2019 cases who retested reverse transcription polymerase chain reaction-positive compared with those that did not test positive (continued)

Description of study

(reference and type,

location and dates of study)

Hu et al., 2020 (9)

Retrospective cohort study

Chongquin, China

Jan 23-Mar 3, 2020

Retrospective cohort study

Wuhan, China

Jan 1-Mar 10, 2020
Report details

Key findings and limitations
- This study followed 221 hospitalized cases. Serology was the main outcome, with serum samples taken every 3 days post-symptom onset.

- Total of 74 cases were discharged and followed for the 14-day quarantine period.

- This study followed 257 hospitalized cases.

- Serology was not main outcome of the study. It is unclear how long cases were followed for or when they underwent serological testing.
- Cases that experienced RP had post-discharge lgG levels of 8.94 on average, compared to 20.19 in NRP cases, which is significantly lower in the RP group. Levels are expressed as a ratio of the chemiluminescence signal to the cut off value (S/CO).

- RP and NRP cases did not have significantly different post-discharge lgM levels ( $0.90 \mathrm{~S} / \mathrm{CO}$ compared with 1.39 S/CO, respectively)

- Reports the highest RP incidence rate of the ten studies ( $n=39 / 74$, or $52.7 \%$ ). No average time to retesting positive was stated.

- No age/sex differences between RP and NRP cases reported.

Limitations:

- Only 74 cases were discharged and followed for the 14-day quarantine period. It was not specified if they were representative of hospitalized patients.

- RP and NRP cases did not differ in rates of testing positive for lgG antibodies ( $94.4 \%$ and $85.1 \%$, respectively).

- RP and NRP cases did not differ in rates of testing positive for IgM antibodies (52.8\% and $58.8 \%$, respectively).

- The incident rate of RP in this study was $20.6 \%$ ( $n=53 / 257$ cases).

- Neither age nor sex was found to differ between RP and NRP cases.

- It is unclear how long cases were followed, but were said to retest positive an average of 4.6 days post-discharge.

- The goal of this study was to compare RP rates for cases with two subsequent negative PCR tests compared to three subsequent negatives to qualify for discharge. $20.6 \%$ of cases with two negative tests experience RP, compared with only $5.4 \%$ of cases with three negative tests.

Limitations:

- Only a subset had serology results (36 RP cases and 114 NRP cases). Information about their difference with those that did not have the test was not mentioned.

- RP and NRP cases did not differ in rates of testing positive for lgG antibodies (100\% and $99.1 \%$, respectively).

- RP and NRP cases did not differ in rates of testing positive for IgM antibodies (75.0\% and $48.2 \%$, respectively).

- The incident rate of RP in this study was $16.7 \%$ ( $n=69 / 414$ cases).

- RP cases in this study were significantly younger than NRP cases. Sex distribution did not differ between groups. discharge from hospital.

Shenzhen, China Jan 11-Apr 23, 2020

- Cases were followed for four weeks following discharge. They retested positive on the day 10 on average, with RT-PCR testing done every $3-5$ days.

Liu et al., 2020 (12)

Cohort study - unclear if prospective or retrospective

Wuhan, China

Mar 1-13, 2020
- This study followed 150 discharged cases.

- Serology was main outcome measure, but neither timing of serology nor duration of follow-up was noted. Testing at different points following discharge may have affected the results.
Limitations:

- It was not specified if the study population was representative of hospitalized patients.

- RP and NRP cases did not differ in rates of testing positive for lgG antibodies (100\% and $90.6 \%$, respectively). Serum levels of lgG antibodies also did not differ between groups (243 AU/mL and $185 \mathrm{AU} / \mathrm{mL}$, respectively).

- RP and NRP cases did not differ in rates of testing positive for lgM antibodies (45.5\% and $47.5 \%$, respectively). Serum levels of IgM antibodies also did not differ between groups (9.6 AU/mL and $8.9 \mathrm{AU} / \mathrm{mL}$, respectively).

- The incident rate of RP in this study was $7.3 \%$ (11/150 cases).

- Neither age nor sex was found to differ between RP and NRP cases.

Limitations:

- Only convalescent patients were followed. It was not specified if they were representative of hospitalized patients.

- The timing of the serological testing is not clear. 
Appendix A: Serological characteristics of discharged hospitalized coronavirus disease 2019 cases who retested reverse transcription polymerase chain reaction-positive compared with those that did not test positive (continued)

\begin{tabular}{|c|c|c|}
\hline $\begin{array}{c}\text { Description of study } \\
\text { (reference and type, } \\
\text { location and dates } \\
\text { of study) }\end{array}$ & Report details & Key findings and limitations \\
\hline $\begin{array}{l}\text { Chen et al., } 2020 \text { (14) } \\
\text { Case-control study } \\
\text { Wuhan, China } \\
\text { Feb 10-Mar 31, } 2020\end{array}$ & $\begin{array}{l}\text { - This study examined the } \\
\text { serology of } 15 \mathrm{RP} \text { cases and } \\
107 \text { controls admitted to a } \\
\text { single hospital. } \\
\text { - Serology was part of a wide } \\
\text { range of factors examined. } \\
\text { Cases were followed up for } 14 \\
\text { days. They retested positive } \\
\text { at day } 12 \text { post-discharge on } \\
\text { average. However, cases were } \\
\text { only tested near the end of the } \\
\text { 14-day quarantine. }\end{array}$ & $\begin{array}{l}\text { - Cases experiencing RP had lgG levels of } 78.53 \mathrm{AU} / \mathrm{mL} \text { on average, compared with } \\
\text { 147.85 AU/mL in NRP cases, which is significantly different. } \\
\text { - Cases experiencing RP had IgM levels of } 13.69 \mathrm{AU} / \mathrm{mL} \text { on average, compared with } \\
68.10 \mathrm{AU} / \mathrm{mL} \text { in NRP cases, which is significantly different. } \\
\text { - Reports the lowest RP incidence rate of the ten studies ( } \mathrm{n}=2 / 107 \text {, or } 1.9 \% \text { ) from } \\
\text { the cohort in a single hospital. Fifteen cases from multiple sites were compared to } \\
107 \text { controls. } \\
\text { - RP cases were found to be significantly younger than NRP cases ( } 43 \text { years } \\
\text { compared with } 60 \text { years). There was no significant difference in sex of RP versus } \\
\text { NRP cases. } \\
\text { Limitations: } \\
\text { - Age and sex were not matched between cases and controls. } \\
\text { - The timing of the serological testing was not clear. }\end{array}$ \\
\hline
\end{tabular}
Abbreviations: COVID-19, coronavirus disease 2019; lgG, immunoglobulin G; IgM, immunoglobulin M; NRP, retested not positive; RP, retested positive; RT-PCR, reverse transcription polymerase chain reaction

Appendix B: Assessment with the Newcastle-Ottawa Scale Risk of Bias Tool of nine studies published up to September 2020, comparing immune response indicators of discharged hospitalized coronavirus disease 2019 cases who retested positive using reverse transcription polymerase chain reaction to those who did not test positive

\begin{tabular}{|c|c|c|c|}
\hline Study & $\begin{array}{l}\text { Selection } \\
(\text { score }=4)\end{array}$ & $\begin{array}{c}\text { Comparability } \\
\text { (score=2) }\end{array}$ & $\begin{array}{c}\text { Exposure/outcome } \\
\text { (score=3) }\end{array}$ \\
\hline $\begin{array}{l}\text { Clinical, immunological and virological characterization of COVID-19 patients } \\
\text { that test re-positive for SARS-CoV-2 by RT-PCR (6). }\end{array}$ & 2 & 0 & 3 \\
\hline $\begin{array}{l}\text { Recurrence of positive SARS-CoV-2 viral RNA in recovered COVID-19 patients } \\
\text { during medical isolation observation (7). }\end{array}$ & 2 & 0 & 1 \\
\hline $\begin{array}{l}\text { Viral RNA level, serum antibody responses, and transmission risk in discharged } \\
\text { COVID-19 patients with recurrent positive SARS-CoV-2 RNA test results: a } \\
\text { population-based observational cohort study (8). }\end{array}$ & 2 & 0 & 2 \\
\hline $\begin{array}{l}\text { Recurrence of positive SARS-CoV-2 viral RNA in recovered COVID-19 patients } \\
\text { during medical isolation observation (7). }\end{array}$ & 2 & 0 & 1 \\
\hline $\begin{array}{l}\text { Clinical features of COVID-19 convalescent patients with re-positive nucleic acid } \\
\text { detection (10). }\end{array}$ & 3 & 0 & 2 \\
\hline The production of antibodies for SARS-CoV-2 and its clinical implication (9). & 3 & 0 & 1 \\
\hline $\begin{array}{l}\text { The issue of recurrently positive patients who recovered from COVID-19 } \\
\text { according to the current discharge criteria: investigation of patients from } \\
\text { multiple medical institutions in Wuhan, China (11). }\end{array}$ & 3 & 0 & 1 \\
\hline $\begin{array}{l}\text { Recurrence of SARS-CoV-2 Positivity of Infected and Recovered Patients: A } \\
\text { Single Center COVID-19 Experience and Potential Implications (13). }\end{array}$ & 4 & 0 & 2 \\
\hline Recurrent positive SARS-CoV-2 - immune certificate may not be valid (12). & 3 & 0 & 2 \\
\hline $\begin{array}{l}\text { Clinical Characteristics of Recurrent-positive Coronavirus Disease } 2019 \text { after } \\
\text { Curative Discharge: a retrospective analysis of } 15 \text { cases in Wuhan China (14). }\end{array}$ & 3 & 0 & 3 \\
\hline
\end{tabular}

